\title{
A first approach to a pay-as-you-go model for a social benefit in Spain
}

\section{Una primera aproximación a un modelo de reparto para una prestación social en España}

\author{
Noemí Peña-Miguel ${ }^{1}$ \\ J. Iñaki De La Peña Esteban ${ }^{1}$ \\ Universidad del País Vasco UPVIEHU (España)
}

Recibido el 7 de noviembre de 2014, aceptado el 17 de octubre de 2015

Publicado online el 4 de mayo de 2016

$\mathrm{N}^{\mathrm{o}}$ de clasificación JEL: H83, M48

DOI: $10.5295 / \mathrm{cdg} .140506 \mathrm{id}$

\begin{abstract}
:
In recent years various domestic and international organisations have proposed financial coverage for the population as a whole. This does not mean that there is currently no coverage: aid in different countries extends to different levels. In this context a universal basic social benefit could be one way of responding to those international proposals. However, such a scheme might be too expensive to be viable, which might lead instead to partial benefits payable to non-workers being considered, as the group in most need of coverage. This paper seeks to analyse whether a model of financing can be found under which a basic minimum social benefit can be implemented in a way that is socially and financially viable and sustainable and can be maintained over time.

Following the usual system for the distribution of budget allocations by public administrations, this model uses a multi-year period - in this case 12 financial years. Spain is presented as a case study, based on a number of forward-looking demographic and economic assumptions in which the various aid systems used in the country's autonomous regions are brought together to provide a minimum coverage.

The main conclusion drawn is that the current level of contributions is sufficient to provide a viable, sustainable partial social benefit. However, a universal benefit would require a considerable increase in extraordinary contributions to meet its cost, though those contributions could be replaced in part by extraordinary state contributions or funding from other sources.
\end{abstract}

\section{Keywords:}

Social Welfare, pay as you go, basic social benefit, Social Security cost.

\section{Resumen:}

Existen organizaciones tanto nacionales como internacionales que en los últimos años proponen una cobertura económica general para la población. No es que no exista un grado de cobertura, sino que los países disponen de unas fuentes de ayudas que alcanzan a ciertos niveles. Ante ello, una prestación social básica universal,

${ }^{1}$ Departamento Economía Financiera I. Facultad de Economía y Empresa de Bilbao, Avda. Lehendakari Agirre 83, 48015 Bilbao (España).noemi.pena@ehu.eus; jinaki.delapena@ehu.eus 
puede ser la respuesta a las anteriores propuestas internacionales. Sin embargo, podría ocurrir que un excesivo coste implicase su no viabilidad y se buscasen coberturas parciales, como una prestación social a abonar a los no trabajadores, al ser éstos los que inicialmente demandarían la cobertura. El objetivo del presente trabajo es analizar un modelo de financiación que haga viable y sostenible económica, social y temporalmente la implantación de la prestación social básica mínima.

Este modelo aun siguiendo un sistema de reparto habitual en los presupuestos de la administración, tiene en cuenta un periodo plurianual de varios años -12 ejercicios económicos. Se realiza una aplicación práctica al caso español bajo una serie de asunciones demográficas y económicas a futuro, donde se constata una pluralidad autonómica de ayudas que se aúnan para conseguir una cobertura mínima.

Como principal conclusión se obtiene que haciendo uso de las cotizaciones actualmente existentes se constata la viabilidad y sostenibilidad de una prestación social parcial. Sin embargo, una prestación universal requiere un aumento considerable de las cotizaciones extraordinarias necesarias financiar su coste, si bien éstas podrían sustituirse en parte por aportaciones extraordinarias del Estado u otros recursos que permitan financiarla.

\section{Palabras clave:}

Bienestar social, reparto, prestación social básica, coste de la Seguridad Social. 


\section{INTRODUCTION}

The idea of a basic social benefit is based on a proposal made by the International Labour Organisation -ILO- (ILO 2012) in regard to basic national social welfare protection systems and a commitment by the European Parliament to see that governments guarantee the basic financial security of their populations (European Parliament 2010). These proposals are in line with the recommendation made by the World Bank in 2005, with the incorporation of a "zero pillar" of social protection (Holzman \& Hinz 2005) referred to as a "non-contributory basic pension".

In Spain the system of contributory social security payments includes the first pillar in the World Bank's proposal, and there is coincidence as to the second and third basic pillars of social protection in place. However, two further pillars are incorporated here: a "zero pillar" comprising a financial allocation sufficient to ensure that all citizens of a country can, each with his/her own possibilities and characteristics, meet the minimum necessities for survival taking into account the demographic and economic circumstances of that country (Cichon \& Hagemejer 2004; Kulke 2007); and a fourth pillar dealing with health services and housing provided mainly by family members. The ILO (ILO 2012) currently proposes a basic level of social welfare protection, acknowledging that social security is a vital tool for public sector social policies to prevent and reduce poverty, inequality, exclusion and social insecurity, promote equal opportunities and prevent discrimination on grounds of race and gender.

In regard to the basic pillar of welfare provision, Spain is not starting from zero. There are already non-contributory minimum benefits available within the Social Security system subject to the minimum financial requirements of households, and the same goes for unemployment benefits. Moreover, authority for managing guaranteed minimum income payments has been devolved to the country's autonomous regional communities (ARCs). In spite of this network of benefits there is no single, integrated system for assuring that all citizens have equal coverage and receive benefits that guarantee a minimum standard of living.

This minimum, common basic coverage needs to be backed by a funding model that can ensure the viability and financial and social sustainability over time of universal basic minimum social benefits (BSB). Those benefits should reach most of the population, and should cover their basic necessities for living.

This paper seeks to establish a funding model under which BSB is viable and financially and socially sustainable over time. Accordingly, the following section examines the characteristics required of a BSB funding model. Section 3 then estimates the cost of implementing such a funding model for benefit payable to the whole population of Spain in 2010 .

Section 4 looks at cost forecasts for the following 12 years under three different demographic and economic scenarios. Finally, the Conclusions section sets out a number of comments and points out the implications of setting the basic level of benefit proposed by the ILO. The paper ends with a list of bibliographic references. 


\section{BASIC FEATURES OF THE FUNDING MODEL}

An actuarial financial system is used to ensure proper coordination between the type and quantity of benefits paid to beneficiaries and the wages for remuneration of contributors included in the provision, so as to forestall any problems of insolvency over time and cater for the resulting socio-economic vicissitudes (De La Peña 2000). The characteristics of the models used depend on the following parameters (ILO 2002):

1. the extent of group solidarity;

2. the level and method of financing; and

3. the sources of funding.

In general, there are three ways of providing financing (ILO 2002):

i. allocation, in which there is hardly any advance funding;

ii. capitalisation; and

iii. capitalisation of risk-bearing capital.

Short-term pension systems are generally funded via the allocation method, because the benefits involved are short-term promises and they can be adapted relatively quickly to changes in demographic and economic circumstances. This means that large financial reserves do not need to be built up to meet funding obligations in the remote future.

In recent years there has been fierce debate in international circles concerning the pros and cons of increasing capitalisation in national pension systems (Beetsma \& Oksanen 2007). Social Security pension systems do not really require the financial security that high levels of capitalisation can provide for small, private systems, but other reasons for adopting capitalisation-based pension systems are frequently given. It is claimed that such systems can increase national savings, since high levels of savings may coincide with low levels of pension reserves and vice versa (Cadarso \& Febrero 2003). Capitalisation is frequently claimed to stimulate growth in capital markets (Doménech 2014), but the proofs of that claim are far from categorical: emerging stock markets have obtained impressive growth rates in countries where there are few, if any, capitalisation-based pension plans. Capitalisation is also said to help insulated pension schemes from the negative effects of ageing (ILO 2002). This may be true in the case of small insured groups within society, or in a small country with in a globalised economy, but it is not true overall for national societies or for globalised society as a whole. Societies have to earmark a certain amount of resources to provide a given level of consumer spending for the elderly. The basic equation for equating income (from contributions and taxation) and expenditure (benefits) does not change if one switches from a wage-based funding system to one based on capitalisation. Ultimately, consumer spending by pensioners must be funded with the current GDP produced by the economically active population (ILO 2002).

However, capitalisation frameworks operate according to the principle that pensioners can sell their financial assets to economically active generations (or use them as collateral) so as to generate cash income. If the purchasing generation becomes smaller then a reduction in the prices of assets can be expected, and this in turn will reduce the retirement income of the next-generation.

To cover this basic benefit it is therefore necessary: 
i) to consider the composition and population demographics of society and a minimum income level required to cover spending on basic necessities;

ii) to allow for a redistribution of income across the whole population based on a responsible attitude on the part of states; and

iii) to allow rapid adaptation to changing needs.

The system that best fits these characteristics is the allocation system (Thullen 1977). This is the most widely used system in Europe for funding social benefits, because it allows annual budget balances to be drawn up. We therefore use this system for financing the implementation of a funding model for universal basic benefits.

\section{THE FUNDING MODEL}

In line with Thullen (1977), actuarial financial equivalence entails the following for the whole funding system

$$
K_{n} \cdot \int_{t_{n}}^{t_{n+1}} S(\tau) \cdot e^{\int_{t_{n}}^{t_{n+1}} \delta(\tau) \cdot d \tau} \cdot d \tau=\int_{t_{n}}^{t_{n+1}} B(\tau) \cdot e^{\int_{t_{n}}^{t_{n+1}} \delta(\tau) \cdot d \tau} \cdot d \tau
$$

where

$S(\tau):$ Sum of the wages of contributing workers for time $\tau$

$K_{n} \quad$ : Percentage of contribution.

$\delta(\tau)$ : Interest rate.

$B(\tau)$ : Pension expenditure function at time $\tau$

$\int_{t_{n}}^{t_{n+1}} B(\tau) \cdot d \tau$ : for the time period $\left[\mathrm{t}_{\mathrm{n}, \mathrm{n}+1} \mathrm{t}_{\mathrm{n}}\right]$ this indicates the total pension expenditure updated to the commencement of the said period.

If in the above equivalence the initial population to be covered at the start of the period $l\left(t_{n}\right)$ is considered in both terms and the expenditure function $B(\tau)$ is split into two factors, $\operatorname{PM}(\tau)$ or the average pension payable at time for the group of beneficiaries $l b(\tau)$, at the commencement of the period the following results:

$$
K_{n} \cdot \int_{t_{n}}^{t_{n+1}} \underbrace{\frac{S(\tau)}{l\left(t_{n}\right)}}_{\begin{array}{c}
\text { Labour } \\
\text { Market }
\end{array}} \cdot e^{\int_{t_{n}}^{t_{n+1}} \delta(\tau) \cdot d \tau} \cdot d \tau=\int_{t_{n}}^{t_{n+1}} \overbrace{\begin{array}{c}
\text { Generosity } \\
\text { of the system }
\end{array}}^{\text {Institutional Factor }} \cdot \underbrace{\frac{l\left(t_{n}\right)}{l\left(t_{n}\right)}}_{\begin{array}{c}
\text { Coverage } \\
\text { of the system }
\end{array}} \cdot e^{\int_{t_{n}}^{t_{n+1}} \delta(\tau) \cdot d \tau} \cdot d \tau
$$

This funding model considers three basic factors that condition its viability and implementation:

i) the demographic factor for the population in question; 
ii) the labour market factor, including the wage bill of the population actually in work as a proportion of the full population;

iii) the institutional factor, which breaks down into two sub-factors:

iii.1) the coverage of the system, which refers to the number of beneficiaries as a proportion of the general population; and

iii.2) the generosity of the system, which refers to the amount of financial benefits paid out, measured according to the purposes of the benefit to be covered.

The theory of insurance states that the viability of the system increases in proportion to the size of the group insured (Vallejo \& Solorzano 2013). This is the theory of large numbers, upon which actuarial calculations are based. Thus, national welfare provision systems with broad coverage generally feature more stable income than systems limited to smaller groups. Moreover, variations in benefits (i.e. the financial risk) among larger groups are inevitably smaller than in smaller groups, which also helps to stabilise their financial position (Jørgensen \& Holzmann 2003).

Doubts are currently being cast on the viability of the current Social Security system in Spain, and a trend is observed towards a division in solidarity groups by autonomous regions. In this context the most extreme case is that of individual accounts. Logically, a tendency for the nationwide, solidarity-based welfare provision system to be broken down into smaller groups which are required to be self-financing inevitably leads to greater disparities in the levels of coverage offered by provisions (García-Núnez 2002). This in turn inevitably leads to inequalities and uncertainty in regard to provisions (ILO 2002).

National social security systems are generally funded via:

1. contributions paid by employers and/or workers;

2. taxation, as a part of the general revenue of the government or with specific taxes levied for this purpose;

$3 . \quad$ revenue from eligible investments; and

4. private payments or insurance premiums.

In practice, most national social security systems are funded from a combination of sources. The above model can therefore be considered with the contributions made by the various public administrations in Spain and taking into account any annual surpluses or losses. Take the following notation:

$A E(\tau):$ Sum of the contributions by the state for time $\tau$

$F N(\tau)$ : Cumulative result at time $\tau$ due to the surplus or loss at that time

Setting up an equalisation fund for each period would give the following:

$$
\begin{gathered}
K_{n} \cdot \int_{t_{n}}^{t_{n+1}} S(\tau) \cdot e^{\int_{t_{n}}^{t_{n+1}} \delta(\tau) \cdot d \tau} \cdot d \tau+\int_{t_{n}}^{t_{n+1}} A E(\tau) \cdot e^{\int_{t_{n}}^{t_{n+1}} \delta(\tau) \cdot d \tau} \cdot d \tau= \\
=\int_{t_{n}}^{t_{n+1}} B(\tau) \cdot e^{\int_{t_{n}}^{t_{n+1}} \delta(\tau) \cdot d \tau} \cdot d \tau+\int_{t_{n}}^{t_{n+1}} F N(\tau) \cdot e^{\int_{t_{n}}^{t_{n+1}} \delta(\tau) \cdot d \tau} \cdot d \tau
\end{gathered}
$$


Given the degree of social welfare coverage provided and the total cost that may be entailed, governments are often unable to finance the system solely from general tax revenue. One widely applied solution is to set up specific social security legislation to fund the system via compulsory contributions that are used exclusively for purposes specified in that legislation. This is the solution that we consider most appropriate.

However, governments may also give a specific mandate to private bodies to finance or co-finance the system and take charge of it, or may decide to leave the matter up to voluntary initiatives. Private services, be they compulsory or voluntary, are often seen as a suitable way of maintaining low levels of public spending (defined broadly to include social security spending funded via contributions). However it is wrong to think that private benefits have no effect on public finances: the government's contingent liabilities are the guarantee of last resort for most social transfers (both public and private) paid to the population. Therefore, even though gross social spending is much higher when social welfare provision is handled by the public sector, net social spending totals more or less the same amount in Sweden, where the welfare provision system is publicly managed in its entirety and in the USA, where it is managed jointly by the public and private sectors. The actual level of spending is practically the same in both countries but the results are radically different in social terms, mainly because privately managed social spending is distributed far more unevenly than public spending (ILO 2002). The financing system used to fund universal basic social benefit in this study is therefore an allocation system funded via contributions paid by employers and/or workers, since we believe that this makes for a more equitable distribution of expenditure across the whole population.

\section{THE COST OF THE MODEL IN SPAIN}

After selecting an allocation-type funding model, the next step is to calculate the estimated cost for the whole population of Spain in 2010, and to estimate the costs for the next 12 financial years. This also necessarily entails defining the benefit to be paid.

\subsection{The Benefit}

The first step is to determine how generous the system is to be, i.e. the actual amount payable as BSB. This amount generally depends on the financial resources available to the central government or autonomous regional community (ARC), on political viability, on whether there are other, analogous benefits that it can replace, etc. (Noguera 2002). However, some researchers propose different amounts, e.g. a universal benefit with amounts differing depending on place of residence, age, family circumstances and other factors (Sanzo 2011; Pinilla 2004, 2006).

The amount payable could also be set arbitrarily according to an external factor (the Multiple Effect Public Income Indicator -IPREM - in Spain) or a regularly set income level (the statutory minimum wage), or indeed it could be set in line with the purpose of the benefit itself, i.e. guaranteeing a minimum level of social protection.

In line with this approach, Peña Miguel et al. (2015) set benefit amounts based on basic or primary necessities for subsistence (food, clothing and footwear, accommodation and 
public transport) (Clark 2005), which people living below the poverty line find it difficult to meet (Guio 2005). They determine the specific factors involved on the basis of the EPF (Spanish Household Budget Survey) for 2010 and other studies (Alcon et al. 2002) that break down spending in Spain.

From this viewpoint, Peña Miguel et al. (2015) define the BSB as a financial assignation paid annually to each citizen that is sufficient to cater for their minimum requirements for survival in accordance with their age, town of residence, employment situation, number of dependents and region of residence (Autonomous Regional Community in Spain). Using an inter-quartile regression model, they also find a quantitative relationship between the amount of total household spending devoted to basic necessities (as a proxy for household income (Aldás et al. 2006)) and the significant factors listed above, which are also the variables or factors used each year in the EPF and in earlier studies (Camacho \& Hernández 2008; Mañas et al. 2002) of the determinants of spending in Spain. They consider that these factors may influence household spending.

Under a simple annual allocation system, the equivalence between the contributions paid in a year and the benefits for outlay in that year is established. The following points must be taken into account in that equivalence:

a) There may be no external funding.

b) Wage-related contributions and contributions from the state used to fund current social welfare benefits can be included, because if BSB is implemented then other aids will clearly be cancelled or phased out. However, no additional budgetary efforts are envisaged, i.e. the budget allocation committed remains the same.

c) A reserve fund may be envisaged for surpluses generated, to cater for unforeseen circumstances, time lags or deficits at certain times, so as to prevent such short-term time lags or deficits from causing imbalances in the funding model.

By applying the quantitative factors obtained from the regression (Peña Miguel et al. 2015) to the sample in the EPF for 2010, the aggregate amount of the benefit and the individual benefits payable to each of the 22,203 individuals surveyed can be obtained. The raising factor ${ }^{2}$ for the National Employment Office (INE) simple is then extrapolated to the complete population in 2010 of 45,147,618 (INE 2010). This results in an average benefit of $€ 3820.48$ per annum for universal coverage, with a total universal benefit expenditure PSBT $_{2010}$ as follows:

$$
\operatorname{PSBT}_{2010}=\int_{t_{n}}^{t_{n+1}} B(\tau) \cdot e^{\int_{t_{n}}^{t_{n+1}} \delta(\tau) \cdot d \tau} \cdot d \tau=€ 172,485,757,349.54
$$

For a partial benefit $P S B P_{2010}$ such as that paid for instance in Canada and Mexico to all those individuals who are not in work (the unemployed, pensioners and other non-wage-

\footnotetext{
2 This is equivalent to the number of people represented by the individual taking the survey and the sum of all the raising factors is equal to the total Spanish population in 2010.
} 
earners) would give an average BSB of $€ 4,694.59$ per annum and a total expenditure on partial BSB $\left(P S B P_{2010}\right)$ as follows:

$$
\operatorname{PSBP}_{2010}=\int_{t_{n}}^{t_{n+1}} B(\tau) \cdot e^{\int_{t_{n}}^{t_{n+1}} \delta(\tau) \cdot d \tau} \cdot d \tau=€ 74,862,618,089.43
$$

The benefits payable to those not in work are equivalent to $43.40 \%$ of the universal BSB for 2010 (Figure 1).

Figure 1

\section{Comparison between partial \& universal BSB for financial year 2010}

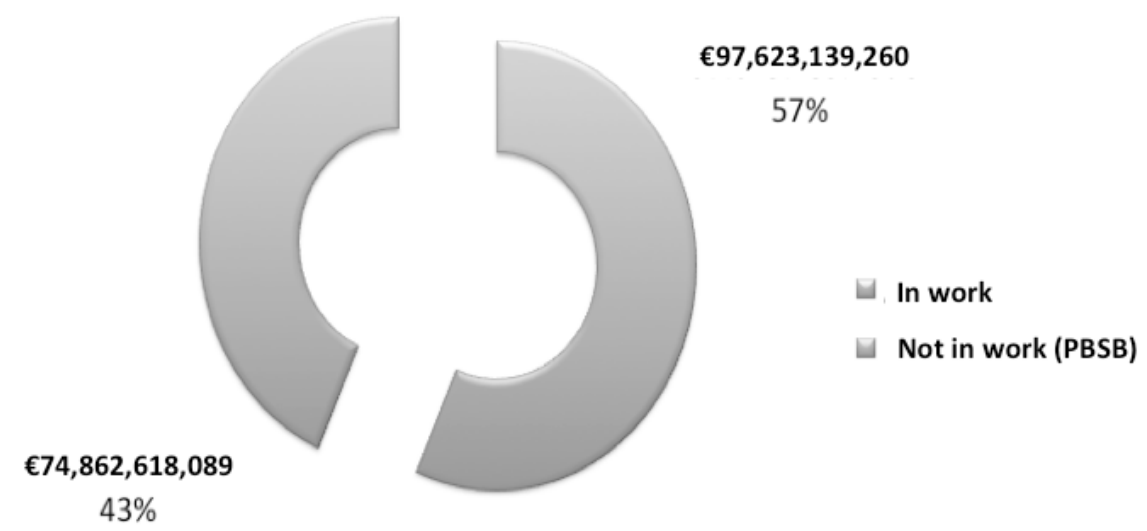

Source: Own elaboration.

\subsection{Funding via contributions only}

Once the amount of the benefit to be paid is determined, it is possible to work out the level of contributions required to fund it exclusively via wages. If other sources of funding are used (employers' contributions via profits, specific taxes, etc) this figure would be reduced, so the initial percentage actually represents the maximum contribution that individuals in work would have to make in order to fund universal or partial benefits, as the case may be.

In Spain the Wage Structure Survey (EES) for 2010 (EES 2010) shows the gross amount paid in wages to the population of the country that year, broken down by age brackets. The amount obtained for the sample is extrapolated to the full number of persons in work in Spain in $2010(18,408,100)$. This figure is obtained from the Labour Force Survey (EPA 2010). The result is as follows:

$$
S_{2010}=\int_{t_{n}}^{t_{n+1}} S(\tau) \cdot e^{\int_{t_{n}}^{t_{n+1}} \delta(\tau) \cdot d \tau} \cdot d \tau=€ 517,909,276,645.35
$$


Universal and partial BSB payments would thus amount to the following percentages of the total wage bill for 2010 in Spain:

$$
\begin{aligned}
K_{n}^{\text {Universal }} & =33.3042 \% \\
K_{n}{ }^{\text {Partial }} & =14.4547 \%
\end{aligned}
$$

This percentage represents the maximum proportion of wage income from workers that would have to be redistributed to fund the BSB for that year. If a universal benefit is considered, then workers themselves also receive a BSB payment in line with their minimum needs for living and their family circumstances. The annual cost of universal BSB thus works out to $16.5 \%$ of GDP for 2010 , while that of partial BSB would be $7.16 \%$.

\subsection{Funding via wage-related and state contributions}

These findings imply that implementing a BSB as a zero pillar of social welfare provision in Spain would simplify minimum benefits, guaranteed minimum income and similar payments and avoid duplications. However it would also mean that the funding currently allocated to such benefits would have to be redirected to fund the level of protection indicated here.

Table 1

Current state contributions that would be subsumed into BSB (in millions of euros)

\begin{tabular}{|l|l|}
\hline \multicolumn{1}{|c|}{ Benefit } & \multicolumn{1}{|c|}{ Contribution in 2010 } \\
\hline Regional guaranteed minimum incomes (100\%) & 766.73 \\
\hline $\begin{array}{l}\text { Non-contributory pensions, social integration \& job placement for the } \\
\text { disabled (LISMI), statutory old-age \& invalidity cover (SOVI) \& other } \\
\text { subsidies (100\%) }\end{array}$ & $13,828.12$ \\
\hline Contributory pensions (35\%) & $37,033.06$ \\
\hline Unemployment: contributory level (85\%) & $20,931.25$ \\
\hline Non-contributory pension quota (100\%) & 142.57 \\
\hline State contributions 2010 & $72,701.73$ \\
\hline
\end{tabular}

Source: Own work based on data from the General Intervention Board of the State Administration (IGAE), Ministry of the Treasury \& Public Administration 2010.

In 2010 a total of $€ 766.7$ million was allocated to guaranteed minimum income (RMI in Spanish) (Ministry of Health, Social Services and Equality 2014). Apart from this aid, the public social security system also provided top-up payments to make up the minimum amounts for pensions and non-contributory benefits for low-income recipients. Such supplements amounted to $€ 8,903$ million that year, out of a total for all subsidies paid out of $€ 13,828$ million (Table 1 ).

BSB would lead to changes in levels of protection. Pensioners would continue to receive their pensions as usual, though they would be funded from different sources. On the one hand they would receive BSB and on the other a supplement based on their contributions 
during their working lives. Within the system for funding BSB it is therefore desirable to consider what proportion of state funding of contributory benefits this benefit would represent.

The contributory benefits paid out by the social security system should therefore be divided into two levels, as proposed by the World Bank. The first would comprise BSB and the second the supplement derived from wage-based contributions. Out of the average contributory pension of $€ 779.49$ per month in 2010 , BSB would cover $€ 272.89$, i.e. $35 \%$. This then is the proportion of the public budget for funding contributory benefits that would need to be earmarked for funding BSB.

Along with the funding earmarked for contributory social security benefits, unemployment benefits would also be affected. The unemployed would receive BSB plus a supplement in line with how much they have contributed and for how long. The part of public spending on unemployment benefit that would be subsumed into BSB must therefore be considered as expenditure, and divided into two levels accordingly. The first comprises BSB and the second the supplement derived from the contributions paid. Out of the average contributory unemployment benefit of $€ 842.40$ per month in 2010, BSB would cover $€ 615.66$, i.e. $85 \%$, so that is the proportion of the budget for contributory unemployment benefits that would have to be earmarked for funding BSB or the basic level.

Together with this funding, the full range of financial resources contributed by the various public administrations to cover the basic level of benefits totals $€ 72,701.73$ million in 2010 (Table 1).

Finally, the "non-contributory pension quota" amount shown is the sum that the ARCs of Navarre and the Basque Country (each of which collects its own taxes and pays a quota to the state under a special agreement) pay in advance to cover pensions in their respective regions that, under their special agreements, are actually payable by the central government. All the non-contributory pensions included under this system are lower than BSB, so they would be subsumed into it and the full amounts currently earmarked for them would go into funding BSB.

\section{12-YEAR SCENARIO}

We have now selected an allocation-funding model and worked out the estimated cost for the whole population of Spain in 2010. Given that future demographic and economic/ labour trends are unknown, it is now necessary to draw up three potential future scenarios. This means establishing demographic and economic forecasts within a given time frame.

\subsection{Introduction}

Changes over time in the population, the economy and the labour market of a country have a direct influence on the financial development of its social security system (Cichon et al. 1999). To study possible trends in the cost of universal and partial BSB over the next 12 years, three potential scenarios are posited here in line with the recommendations of European Economy (2/2012). 
In each scenario the demographic, economic and labour-market conditions envisaged as prevailing in the coming 12 years are set. Given that the base year is 2010 and confirmed figures are already available for the demographic, economic and labour-market situation in 2011 and 2012, the data are adjusted accordingly in setting up the scenarios.

The following five variables are used to make up each scenario:

1) Population structure by age, to gauge the demographic trend (potential contributors and number of pensioners expected in the coming years). The general population data required are the following (Plamondon et al. 2000):

- $\quad$ Population broken down by age and gender

- $\quad$ Percentage for fertility \& breakdown per gender of births

- $\quad$ Percentage for mortality (PE 2000 NP survey of the general population in Spain)

- $\quad$ Percentages for immigration and emigration and their variations.

2) Economic trend. The main variables that report on the state and development of the economy are the following:

2.1) GDP.

The percentage of GDP earmarked for BSB serves to measure how much an efficient, foresighted public administration could spend without getting into difficulties in circumstances of all kinds, including the most adverse (Casassas \& Raventós 2011).

2.2) Variations in the consumer price index (CPI) for the basic products to be covered with BSB. Given that the funding model posited sets out to fund BSB for the next 12 years, and given that BSB covers expenditure on basic necessities, variations in the price of those necessities must be taken into account.

2.3) Variations in the benefit updating rate. The 12 year time-frame envisages an interest rate for updating the relevant values, free from investment risk.

3) Labour market: the main variables that determine the structure of and potential changes in the labour market are the trend in wages and the variation in the number of people who switch from one employment status to another ${ }^{3}$.

Table 2

Technical basis for the three scenarios

\begin{tabular}{|l|l|l|l|}
\hline & \multicolumn{1}{|c|}{ PESSIMISTIC } & \multicolumn{1}{c|}{ BASELINE } & \multicolumn{1}{c|}{ OPTIMISTIC } \\
\hline & SCENARIO 1 & SCENARIO 2 & SCENARIO 3 \\
\hline \multicolumn{5}{|c|}{ DEMOGRAPHIC TREND } \\
\hline Fertility percentage & $90.00 \%$ & $100.00 \%$ & $110.00 \%$ \\
\hline Immigration percentage & $90.00 \%$ & $100.00 \%$ & $110.00 \%$ \\
\hline Emigration percentage & $110.00 \%$ & $100.00 \%$ & $90.00 \%$ \\
\hline Mortality percentage & PE 2000 NP & PE 2000 NP & PE 2000 NP \\
\hline \multicolumn{5}{|l|}{ ECONOMIC TREND } \\
\hline Variation in GDP & $0.00 \%$ & $1.00 \%$ & $2.00 \%$ \\
\hline
\end{tabular}

3 For instance individuals who switch from employed to unemployed, employed to retired or unemployed to employed, and people who join the workforce for the first time. 


\begin{tabular}{|l|l|l|l|}
\hline $\begin{array}{l}\text { Variation in updating } \\
\text { rate }\end{array}$ & $1.50 \%$ & $2.00 \%$ & $3.00 \%$ \\
\hline $\begin{array}{l}\text { Variation in CPI of BSB } \\
\text { products }\end{array}$ & $3.00 \%$ & $2.00 \%$ & $1.50 \%$ \\
\hline \multicolumn{2}{|c|}{ LABOUR MARKET } & MARE \\
\hline Trend in wages & $0.00 \%$ & $1.00 \%$ & $2.00 \%$ \\
\hline Trend in unemployment & $3.00 \%$ & $0.00 \%$ & $-3.00 \%$ \\
\hline
\end{tabular}

Source: Own elaboration.

\subsection{Scenarios}

The pessimistic scenario is characterised by a negative trend in all variables. In other words the demographic trend shows a moderate decrease in immigration rates and a moderate increase in emigration rates, resulting in a net population decrease. The economic trend is negative due to stagnation of the GDP, a positive but low benefit updating rate and increases in CPI far greater than those in wages, thus significantly decreasing purchasing power. The labour market suffers from stagnation in wages and increasing unemployment rates, with the resulting fall in the number of persons in work.

Under the baseline or neutral scenario all variables are assumed to follow a constant trend with no significant fluctuations. This means that the demographic trend shows only non-significant variations in immigration and emigration rates. There is stagnation in the economic trend due mainly to GDP growth so low that it is close to stagnation, benefit updating rate that is positive but moderate and increases in CPI slightly greater than those in wages. The labour market undergoes slight wage increases and unemployment rates remain steady, with the resulting stagnation in the number of persons in work.

The optimistic scenario is characterised by a positive trend in all variables. The demographic trend shows a moderate increase in immigration rates and a moderate decrease in emigration rates, resulting in a net increase in population. The economic trend is positive, with a positive updating rate and increases in CPI lower than those in wages, thus increasing purchasing power. The labour market shows a moderate increase in wages and falling unemployment, so that the number of persons in work increases.

Finally, the demographic trend expected for the next 12 years (European Economy 2012) is one of slight growth, with a population increasing from 46 million in 2010 to 48.1 million in 2020.

\subsection{Results}

Depending on the variables compared, and on the basis of the hypothetical trends set out above, the interval where the BSB system can be found and its trend over the next three legislatures (12 years) can be observed.

Figures $2 \& 3$ show the intervals in the yearly contribution percentages as a proportion of the total wage bill for persons in work required to fund universal or partial BSB. In all cases an upward trend is expected in regard to payment of the benefit (be it universal or partial), with the state contributions (SC) currently used to fund similar benefits being 
included in the funding of the BSB. This means that there are parallel decreases in the percentages of contributions in all three scenarios.

For universal benefit the three values range from $21.98 \%$ for the pessimistic scenario, $21.13 \%$ for the neutral one and $20.29 \%$ for the optimistic one in 2010 to $40.28 \%, 30.16 \%$ and $24.00 \%$ respectively in 2021 (Figure 2).

If state contributions are not included the three values are $34.30 \%$ for the pessimistic scenario, $32.97 \%$ for the neutral one and $31.67 \%$ for the optimistic one in 2010 , and $53.17 \%, 42.64 \%$ and $36.07 \%$ respectively in 2021 .

Figure 2

\section{Comparison of forecast for universal BSB with \& without state contributions (SC)}

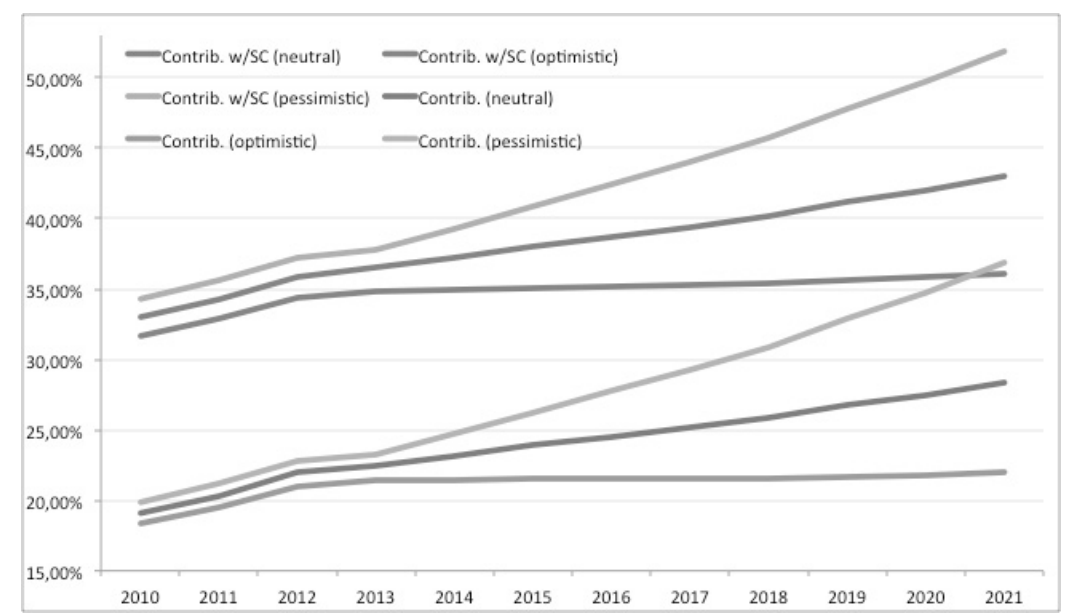

Source: Own elaboration.

However, the contributions for partial BSB including state contributions (SC) are not so high: they range from $2.56 \%, 2.47 \%$ and $2.37 \%$ for the pessimistic, neutral and optimistic scenarios in 2010 to $11.35 \%, 6.91 \%$ and $4.28 \%$ in 2021, as can be seen in Figure 3.

The contributions required for partial BSB not including SC are no higher: they range from $14.89 \%, 14.31 \%$ and $13.75 \%$ for the pessimistic, neutral and optimistic scenarios in 2010 to $24.23 \%$, 19.38\% and 16.36\% in 2021, as also shown in Figure 3. 
Figure 3

Comparison of forecast for partial BSB with \& without state contributions (SC)

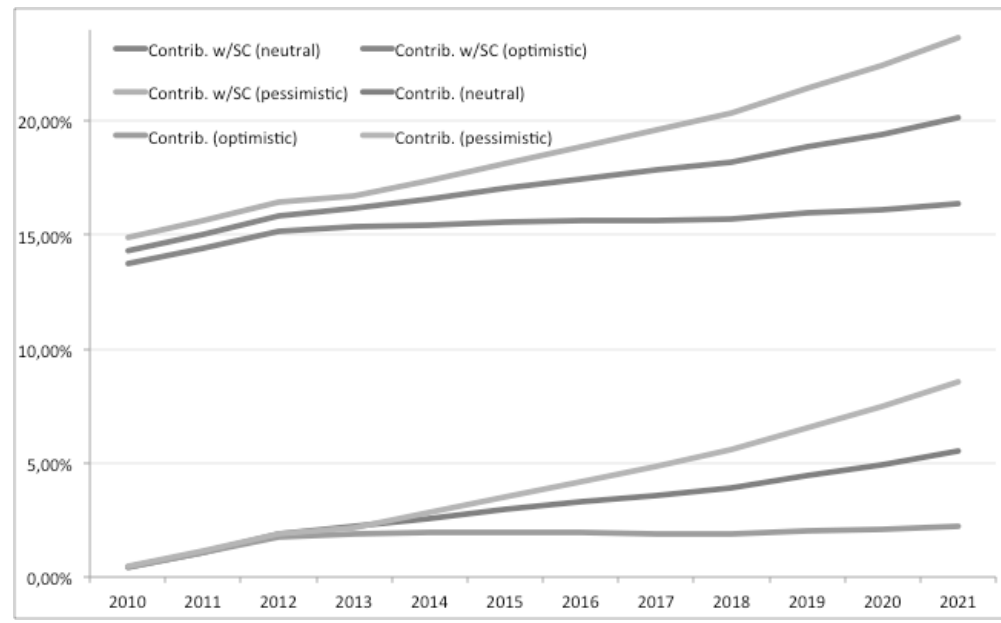

Source: Own elaboration.

\section{CONCLUSIONS AND IMPLICATIONS}

Setting up a basic pillar of public social welfare provision in Spain necessarily entails determining the extent of the network of provision measures currently in place. That network includes aids, incomes and minimum benefits funded at regional or local level in line with devolved authority, or at national level, so a basic level of social welfare provision can be said to exist already. However, it is not applied consistently nationwide so there is really no common overall benefit per se. The current system of aids has major problems which limit its effectiveness in reducing inequality and poverty in Spain. BSB would remedy the inconsistencies and shortcomings found in the many schemes now in place, which result in differences in the protection provided for different population groups.

Using an allocation-type funding model means that income can be transferred from one generation to another and benefits can be assured with the resources available in each financial year. In spite of the criticism levelled at this model on the grounds that it takes a short-term view (spending and revenues for each financial year), it supports feedback in resources and sustainability over time if prudent, appropriate forecasts and provisions are implemented so as to maintain a suitable standard of coverage for the population.

The introduction of BSB would mean that the second tier of the system (the contributory pillar) would have to be restructured. On retirement all individuals would receive BSB in line with their personal circumstances (place of residence, age, dependents, etc.). If the contributions that they have made over their years in work entitle them to an amount lower than BSB, that amount would be topped up to the minimum BSB. If their entitlement is greater they would receive a supplement over and above BSB in line with their actual contributions. 
Our findings here lead us to conclude that it would be viable and sustainable to set up a scheme for BSB covering that part of the Spanish population which does not generate any resources in the form of wages.

The scenarios examined indicate that universal BSB would be very costly in terms of the percentage of the total wage bill of persons in work required to fund it, but that the cost would not be so high for partial BSB, and that a partial protection system could be set up and provisioned in practice to cover all those individuals not in work, providing them with sufficient income to cover the basic necessities of life.

\section{REFERENCES}

Alcón, EM; Quiñones, PG and Bermejo, L.R., 2002. Household Services in Spain: Some Key Explanatory Factors. The Service Industries Journal, 22 (1), 92-121.

Aldás, J.; Goerlich, F.J. and Ivars, M. Mas, 2006. Gasto de las familias en las Comunidades Autónomas españolas (1998-2002): Pautas de consumo, desigualdad y convergencia. CIEF Centro de Investigación Económica y Financiera. Santiago de Compostela: Fundación Caixa Galicia, 259.

Beetsma, R. and Oksanen, H., 2007. Pension Systems, Ageing and the Stability and Growth Pact. European Economy Economic Paper, 289. (Visited, May, 21, 2015) in http:// ec.europa.eu/economy_finance/publications/publication9491_en.pdf

Cadarso, M.A. and Febrero, E., 2003. Sistemas de reparto versus sistemas de capitalización: Algunas reflexiones críticas. Madrid: X Jornadas de Economía Crítica. 25-27 Marzo (visited on May, 20, 2015).

Camacho, J. and M. Hernández, 2008. Detección e influencia de los principales factores explicativos del consumo familiar de servicios en España y sus regiones. Revista de Estudios Regionales, 82, 185-209.

Casassas, D. and Raventós, D., (Eds.) 2011. La Renta Básica en la era de las grandes desigualdades. Barcelona: Editorial Montesinos.

Cichon, M.; Scholz, W.; Van der Meerendonk, A.; Hagemerjer, K. Bertranou, F. and Plamondon, P. 1999. Financing Social protection. Géneva: International Labour Office.

Cichon, M. and Hagemejer, K., 2004. Cambios en el paradigma de las políticas de desarrollo: inversión en una seguridad social mínima para todos. Revista Internacional de la Seguridad Social, 57.1.

Clark, D., 2005. Sen's Capability Approach and the Many Spaces of Human Well-being. The Journal of Development Studies, 41, 8, 1139-1368.

De La Peña Esteban, J.I., 2000. Planes de Previsión Social. Madrid: Editorial Pirámide.

Doménech, R., 2014. Pensiones, bienestar y crecimiento económico. Documentos de Trabajo BBVA Research 14/03.

Encuesta de Estructura Salarial-EES-, 2010. Instituto Nacional de Estadística -INE-.

Encuesta de Población Activa -EPA-, 2010. Instituto Nacional de Estadística -INE-.

Encuesta de Presupuestos familiares -EPF-, 2010. Instituto Nacional de Estadística -INE-.

European Parliament, 2010. Role of minimum income in combating poverty and promoting an inclusive society in Europe. European Parliament resolution 2010/2039 (INI).

European Economy, 2012. The 2012 Ageing Report. Economy and budgetary projections for the 27 EU MEMBER States (2010-2060). 
García-Núñez, F., 2002. Los complementos autonómicos:¿Seguridad Social o Asistencia Social?. Revista Ministerio de Trabajo y Asuntos Sociales, 34, 129-167.

Guio, A., 2005. Material deprivation in the EU. In: EUROSTAT Statistics in Focus. Luxemburgo: Oficina de Publicaciones Oficiales de las Comunidades Europeas..

Holzmann, R. and Hinz, R., 2005. Old-Age Income Support in the 21st Century. An International Perspective on Pension Systems and Reform. Washington: World Bank.

ILO, 2012. Social protection floors for social justice and a fair globalization. International Labour Conference, 101st Session.

ILO, 2002. Seguridad Social: un nuevo consenso. Ginebra: Oficina Internacional del Trabajo.

INE, Instituto Nacional de Estadística-, 2010. Población española. http://www.ine.es (visited on January, 18, 2015).

Jørgensen, S. and Holzmann, R., 2003. Manejo social del riesgo: un nuevo marco conceptual para la protección social y más allá. Revista Facultad Nacional de Salud Pública, 21 (1), 73-106.

Kulke, U., 2007. Cometido presente y futuro de las normas de la OIT en la materialización del derecho a la Seguridad Social, Revista Internacional de la Seguridad Social, 60.

Mañas, E.; Cuadrado, JR. and Galbadon, P., 2002. El consumo de los servicios en los hogares españoles. Instituto de Estudios Económicos, 325-332.

Ministry of Health, Social Services and Equality, 2014. Social Services Public System. http://www.msssi.gob.es/ (visited on February, 20, 2015)

Ministry of the Treasury and Public Administration, 2010. General Intervention Board of the State Administration (IGAE) http://www.igae.pap.minhap.gob.es/sitios/igae/es-ES/ Paginas/inicio.aspx (visited on February, 15, 2015)

Noguera, J., 2002. ¿Renta Básica o Trabajo Básico? Algunos argumentos desde la teoría social. Sistema: Revista de ciencias sociales, 166, 61-86.

Peña Miguel, N.; De la Peña, J.I. and Fernández Sainz, A., 2015. Main Factors for a Proposal for a Social Protection Floor. Social Indicators Research, 123, 59-76.

Pinilla, R., 2004. La Renta Básica de ciudadanía. Una propuesta clave para la renovación del estado del bienestar. Barcelona: Icaria Editorial.

Pinilla, R., 2006. Más allá del bienestar. La renta básica de la ciudadanía como innovación social basada en la evidencia. Barcelona: Icaria Editorial.

Plamondon, P.; Drouin, A.; Binet, G.; Cichon, M; Mcgillivray, W.R.; Begard, M. and Perez-Montas, H., 2000. Actuarial practice in social security. Géneva: ILO/ISSA.

Sanzo L, 2011. Renta Básica y Protección Social en España, en La Renta Básica en la era de las grandes desigualdades. Casassas y Raventós. Barcelona: Editorial Montesinos.

Thullen, P., 1977. Mathematische Methoden der Socialen Sicherheit: Systeme der Invaliden Alters-und. Karlsruhe-Werl: Ed. Buch. Versicherungswirtschaf.

Vallejo, B. y Solórzano, M., (Coord.), 2013. Gestión Patrimonial y Banca privada. Madrid: Ed. McGraw-Hill. 
